itself: "Pouring the molten glass into the mold took seven hours; the disk was then sealed in the annealer, where it remained, cooling slowly, for many months." Grinding the mirror, which removed more than five tons of glass while exposing many slight flaws, took several more years.

The story of Mount Palomar Observatory makes fascinating reading, livened up as it is by one of those monumental battles of egos that often accompanies the doing of great deeds. Here, the conflict was between Hale and the president of the Carnegie Institution, John Merriam, who was vying for ownership of the telescope.

Goodstein, Caltech's archivist for 20 years, has produced a cleanly written, scientifically well informed account of

\section{Missing the biotech boat}

\section{Alfred E. Middleton}

The Biotechnologists. By Stephanie Jones. Macmillan: 1992. Pp. 252. £25.

How to describe The Biotechnologists? An impressionistic oral history of the biotechnology business? A primer for those considering starting up and running a biotech company? A comparison of the similarities and differences between biotechnology in the United States, Europe and Japan?

Any one of these is a more apt depiction of the essence of this book than the author's full-blown aim: "the analysis of the progress of biotechnology start-up companies in the USA and Europe through the perspective of the biotechnologists who founded them and/or now run them." To capture this perspective, Jones interviewed ten biotechnology chief executives and five venture capitalists in the United Kingdom and Europe, and nine biotechnology chief executives and one venture capitalist in the United States. All the US chief executives she interviewed were from socalled 'first generation' companies founded between 1978 and 1982, that is, from companies far removed from their startup stages.

Jones has divided her book into three disparate sections: a preface in which she attempts to outline rules and models for the stages of a biotechnology company's growth; an introduction in which she competently relates the history of commercial biotechnology, particularly in the United Kingdom, and compares biotechnology in various countries; and the core, the interviews.

One large and several smaller mistakes compromise the effectiveness of one of the world's foremost institutions for science and technology. Whether reading about Linus Pauling and the nature of the chemical bond, Charles Lauritsen's work with high-energy $X$ rays, or relishing the unintentionally amusing boasts of the institute's former presidents ("There are no good appointments at Caltech - only superb ones. Of course, occasional mistakes occur ...."), one will come away convinced that, with its 21 Nobel prizewinners and its 1,800 students bearing nearperfect entrance-test scores, this was and is one of the chosen Valhallas of latterday science.

Ed Regis is a college scholar at Western Maryland College, Westminster, Maryland 21157, USA.

the book. Jones conducted her interviews in the United Kingdom and Europe during the winter of 1989-90, and in the United States during the summer of 1990. From then to the book's publication in January 1992, she committed a blunder of grievous proportions by impersonating Rip Van Winkle, slumbering through 1991 and completely ignoring what was happening last year in US biotechnology.

Last year was a watershed period in US biotechnology. Amgen became the industry's leader, doubling its revenues to $\$ 699$ million and dramatically increasing its profits - by 2,400 per cent - on the strength of sales of its two drugs, Epogen (EPO) and Neupogen (G-CSF). Starting in March 1991, 39 biotechnology companies floated initial public offerings, raising a total of $\$ 1,200$ million or an average of more than $\$ 30$ million apiece. Of these companies, about 21 were less than 3 years old, nullifying Jones's statement that "after 5 to 7 years, or perhaps much longer, a biotech enterprise may be ready to go public". In some cases, the initial public offerings were so well received and share prices maintained so well that these newly public companies were able to return to the public markets in a few months with second issues. A total of 88 separate US biotechnology stock issues were consummated in 1991, garnering more than $\$ 4,000$ million. Several of the US biotechnology companies whose chief executives Jones interviewed, raised additional capital through public offerings (Genzyme, \$142.9 million; RepliGen, \$25 million).

Genetics Institute, whose chief executive, Gabriel Schmergel, was interviewed by Jones, lost a patent dispute to Amgen in March 1991 and was the target of a two-tier takeover offer by American Home Products for 60 per cent of its stock in November. Chiron acquired Cetus during the summer, creating a combined company of 1,400 people and a launching pad for further growth. All these events strengthened US biotechnology, created formidable competition for biotechnology companies in other countries and put pressure on companies such as British Biotechnology to increase their capital base; yet Jones does not acknowledge them even in an epilogue.

While duplicating a section of Robert Teitleman's Gene Dreams (Basic Books, 1989; see Nature 342, 25; 1989) and being influenced by his pessimistic tone, Jones fails to pick up on the strongest feature of that book - the incisive personality and character descriptions. In her hands, the executives and venture capitalists are ciphers. We know them only by their words, not hers.

Consider the description in Gene Dreams of Robert Nowinski, one of the founders of Genetic Systems: "a strong, aggressive personality; a quick wit, boundless confidence - capable of thinking in large conceptual terms, an able fund raiser, quick to organize a team to follow his lead". You get a sense of a formidable presence. Nowinski was one of the three co-founders of Icos, along with George Rathmann, former chairman of Amgen, whom Jones interviewed. Rathmann comes across in The Biotechnologists as a practical, commonsense individual. His advice on funding: "get as much money as you can - go public when the time is right". Last September, Rathmann ousted Nowinski, the company's largest shareholder, from Icos. As well as his practical mind, Rathmann must have very sharp elbows indeed, but you would not know it from Jones.

Jones turns on her tape recorder and the interviewees ruminate. She makes no attempt to steer the monologues to critical issues - pricing, patents, government regulation. Those making the most outrageous statements stand out. Jim Vincent of Biogen wins for his comments on the superiority of US business, science and management. Herbert Schoemaker of Centocor is a close runner-up with his statement, "in a recent wave of forming start-ups, 1,200 new biotech companies have been formed". Thoughtful, perceptive statements such as those of Keith McCullach of British Biotechnology get lost in the shuffle.

As an oral impressionistic history of biotechnology, The Biotechnologists passes muster. To paraphrase John Dalton a century earlier, this book will no doubt be found interesting by those who take an interest in it.

Alfred $E$. Middleton is vice president of The Neil Michael Group, Inc., 305 Madison Avenue, Suite 902, New York. New York 10165, USA. 